This item was submitted to Loughborough's Research Repository by the author.

Items in Figshare are protected by copyright, with all rights reserved, unless otherwise indicated.

\title{
Reframing Amy Levy: photography, celebrity, and posthumous representation
}

\section{PLEASE CITE THE PUBLISHED VERSION}

https://doi.org/10.3366/vic.2022.0447

\section{PUBLISHER}

Edinburgh University Press

VERSION

AM (Accepted Manuscript)

\section{PUBLISHER STATEMENT}

This is an Accepted Manuscript of an article published by Edinburgh University Press in Victoriographies. The Version of Record is available online at: http://www.euppublishing.com/doi/abs/10.3366/vic.2022.0447.

\section{LICENCE}

CC BY-NC-ND 4.0

\section{REPOSITORY RECORD}

Parker, Sarah. 2022. "Reframing Amy Levy: Photography, Celebrity, and Posthumous Representation". Loughborough University. https://hdl.handle.net/2134/16719241.v1. 


\section{$\underline{\text { Reframing Amy Levy: Photography, Celebrity and Posthumous Representation }}$}

Reanimating the dead is the latest trend on the internet. Genealogy website MyHeritage recently enabled people to animate photographs of deceased relatives (or long-dead authors) using AI technology they call Deep Nostalgia ${ }^{\mathrm{TM}}$. Meanwhile, the YouTube channel 'poetryreincarnations' features over a hundred videos of jerkily animated poets 'reading' their work. In the late-Victorian poet Amy Levy's case, she does not read her own poetry, but 'The Return' by Ezra Pound. ${ }^{1}$ Viewing the video makes for a disturbing experience, as it funnels someone else's words - and an antisemite, at that - through Levy's awkwardly animated mouth [Figure 1]. But although this tasteless response might seem characteristic of our contemporary moment, this 'reanimation' of Levy is in fact only the latest in a long history of misrepresentative, bordering on exploitative, uses of her image. The manipulative reframing of Levy began in the late nineteenth century, at the moment of her death.

Following her suicide in September 1889, a number of commentators set to work reanimating Levy in order to support their own ideas about female education, genius and 'madness', degeneration, and Jewish identity. In this article, my analysis of these responses reveals that writers repeatedly place their focus on Levy's appearance, as her photograph becomes the catalyst for various 'imaginary portraits.' Contemplating these 'reframed' representations of Levy, I ask: how did authors reshape Levy's image to suit their own requirements, and to support their agendas in relation to late nineteenth-century debates? What different 'mythologies' of Levy emerge in these posthumous accounts, and what cultural materials do they draw on? How does Levy's photograph become a battleground of interpretation after her death, as well as an object of memorialisation? Finally, as Levy's work and her image became a contested site for various cultural interpretations, what are the implications for her legacy, and for the legacies of the other late-nineteenth and twentieth-century women poets that followed in her wake? 
While Levy was certainly ambitious, her attitude towards celebrity was rather ambivalent - at least judging from her works. The hunger for recognition is one of the many unassuaged appetites expressed in poems such as 'A Minor Poet,' in which the suicidal speaker turns to Shakespeare and Goethe, but willingly surrenders his own claim on worldly renown. Another lyric asks: 'O is it Love or is it Fame, / This thing for which I sigh? / Or has it then no earthly name / For men to call it by?' (398). ${ }^{2}$ Rather than fame, Levy's speakers long for a sympathetic listener or reader, who usually materialises too late, when they do appear at all. This echoes Levy's own trajectory towards literary celebrity. At the time of her death, she was steadily gaining critical recognition for her early poetry and her first novel, The Romance of a Shop (1888). The controversy surrounding her second novel Reuben Sachs (1888), closely followed by her suicide, propelled her into the realms of full-blown literary celebrity, fuelling the success of $A$ London Plane-Tree and Other Verse (1889), and precipitating the reissuing of $A$ Minor Poet and Other Verse in 1891. For Levy, fame was most certainly a posthumous attainment, founded on the mythologising of her early death. Since her image was still in the process of formation at the time of her death, it was relatively easy for commentators to embellish her life and character - a fantasising process that took her photograph primarily as inspiration.

\section{Portrait of A Minor Poet: The Montabone Photograph}

Levy's life and, more specifically, her death, is riddled with misconceptions. Immediately following her suicide, her close friend Clementina Black went on the defensive, correcting 'various reports, some exaggerated and some wholly untrue, $[\ldots]$ made in various papers', including that Levy 'suffered from failing eyesight' and that she 'devoted herself to work in the East End' (457). In doing so, Black inadvertently generated some distortions of her own, 
stating that Levy barely 'left her father's house' and that her suicide was brought on by 'strenuous brain work' (457). Myths around Levy continued to proliferate in the twentieth century; for instance, in 1912, Warwick James Price describes Levy as a 'Clapham factory girl' who lived in a 'cob-webbed garret' (370). Levy was in fact living in her parents' home at 7 Endsleigh Gardens, Bloomsbury at the time of her death; a comfortable, middle-class abode. ${ }^{3}$ Price's misunderstandings arise from interpreting Levy's poetry autobiographically. For example, in 'A London Plane-Tree,' Levy's speaker declares: 'Here from my garretpane, I mark / The plane-tree bud and blow' (385). Price also draws liberally on 'A Minor Poet' (a dramatic monologue in the form of a suicide note), assuming that it reflects the real conditions of Levy's existence above an 'endless sea of London roofs' (374); one of several lines he paraphrases as supposedly expressing Levy's own thoughts at the moment of her suicide.

Such posthumous responses are consistently mediated by Levy's portrait which appeared in the press following her death. The only 'publicity' photograph of Levy was taken at the Montabone studio in Florence in January 1889 [Figure 2]. Luigi Montabone, an Italian photographer, opened a series of studios in Rome, Turin, Milan, and Florence. Levy had the photograph taken at the end of her final trip to Florence, which began in November 1888, the last of several sojourns there since 1886. There are of course other photographic images of Levy in existence, beyond the Montabone portrait, some of which are reproduced in Linda Hunt Beckman and Christine Pullen's biographies. These are, however, private, informal images from the Levy family albums, rather than intended for public use. While Levy welcomed photographs of friends and relations, she was ambivalent about being represented herself, a fact which partly accounts for the dearth of public images circulating during her lifetime. ${ }^{4}$ For example, in a letter from Switzerland in 1882, she writes: 'opposite to me is E.C. being sketched by Miss Cross to whom I am also going to sit; at least Miss Cross offered 
me a model, but I hope it won't come off, for I hate sitting' (qtd. Hunt Beckman 241-2). Although it is unclear if 'Miss Cross' sketched Levy on this occasion, Levy's diary entry for March 12, 1889 records 'sat to E. Cross' (qtd. Pullen 149), suggesting that a portrait may have been created after all, though it is not included in either biography. ${ }^{5}$ A pencil sketch of Levy by Grace Black (sister of Clementina), created around 1881, does exist, but once again, this is a private image, rather than one intended for public circulation. ${ }^{6}$

But despite this lack of public portraits, Levy was certainly interested in photography, particularly as a profession that was increasingly open to women. This is demonstrated in her novel The Romance of a Shop (1888), in which the Lorimer sisters set up their own studio. Levy's novel displays technical knowledge of photographic processes, including tripods, chemicals ('pyrogallic acid and acetate of soda'), slides and other equipment (78). Through her novel, Levy also uses photography to contemplate issues of the gendered gaze, reflecting her own ambivalence about being 'captured'. Although the sisters wield the camera, they are subject to the objectifying gazes of others, whether it be Aunt Caroline's horrified glare when spotting Gertrude at the top of an omnibus, or the artist Sidney Darrell's coldly assessing gaze, which causes her to shrivel with discomfort. Darrell's possessive gaze ultimately leads to Phyllis's death from consumption - a fate foreshadowed when Gertrude is commissioned to photograph a female corpse: 'haggard with sickness, pale with the last strange pallor, but beautiful withal, exquisitely, astonishingly beautiful' (92). Phyllis's admiration for this photograph anticipates her destiny; to repeat this 'wicked' woman's fate, becoming Darrell's muse/victim, and an equally beautiful corpse. The scene in which Gertrude views Phyllis's body replicates the earlier encounter:

In her long narrow coffin lay Phyllis; beautiful and still, with flowers between her hands. $[\ldots]$ On the breast of the dead girl lay a mass of pale violets which Lord 
Watergate had sent the day before, and as Gertrude looked, there flashed through her mind, what had long since vanished from it, the recollection of Lord Watergate's peculiar interest in Phyllis.

It was explained now, she thought, as the image of another dead face floated before her vision. That also was the face of a woman, beautiful and frail; of a woman who had sinned. She had never seen the resemblance before; it was clear enough now. $(181-182)$

Gertrude's memory generates a composite photograph, as Phyllis's image is superimposed onto the earlier image of Lady Watergate. The kinship between the women is reiterated throughout the novel; they share an uncanny physical resemblance and, in sitting for Darrell's paintings, both become lifeless images prior to their untimely deaths. When laid out for burial, both women are staged as aestheticised objects, with Phyllis holding violets as in Darrell's earlier painting (137). Following their deaths, both Phyllis and Lady Watergate are posthumously 'framed' by others; as 'wicked', as helpless victims, as a warning. Although she could not know it at the time of writing her novel, this was to be Levy's fate too, as her own posthumous portrait also came to function as a cautionary tale.

In early January 1889 , Levy evidently decided to have her photograph taken by Montabone - perhaps because she knew that her star was on the rise. Her second novel, Reuben Sachs, had just been published, and she was about to publish a third (Miss Meredith) and a second collection of poetry, A London Plane-Tree and Other Verse. As Hunt Beckman shows, Levy's calendar for 1889 was busy; anonymity was no longer a viable option. With this level of public exposure, Levy needed an image to represent her, and the Montabone photograph fulfils that purpose. It depicts Levy clad in a dark, pleated gown, with an intricate lace collar. She gazes directly into the camera, with a serious, slightly wistful expression. A 
few strands of dark hair play around her face and neck, as the camera picks out details of texture and movement. This image was first published in Woman's World in 1890, alongside Oscar Wilde's obituary [Figure 3]. It was then used as frontispiece to the re-released edition of $A$ Minor Poet and Other Verse published by T. Fisher Unwin in 1891, as part of the 'Cameo' series [Figure 4]. Thus, the public encountered Levy's image for the first time when also receiving the tragic news of her death. Their responses to her face are therefore filtered through the knowledge of her suicide, which was widely reported in the press. For example, the Pall Mall Gazette, promoting the new edition of $A$ Minor Poet, writes:

The appearance, among the delicately clad ranks of the 'Cameo Series,' of a second edition of 'A Minor Poet' bears witness to the interest taken in the strange, clever, melancholy girl who but lately chose to follow Chatterton and join 'the inheritors of unfulfilled renown.' That interest is as much in a personality as in a poet, and we have no doubt therefore that the sketch of Miss Levy and of her brief life which a contributor sends will be welcome to many readers. ('The Tragedy of Amy Levy' 3)

An account of Levy's life and work by 'R. B. J.' (unidentified) follows. This biographical 'sketch' is accompanied by a different kind of 'sketch' - a drawing based on the Montabone photograph, captioned 'From the frontispiece to the new edition' [Figure 5]. Levy's appearance is thus linked to her 'personality,' and both are placed on an equal plane of 'interest' to her work. As we have already seen with Price, reviewers tend to assume that Levy's poems offer access to her inner thoughts. In this sense, she was compared to the Ukranian artist Marie Bashkirtseff, who also died young (of tuberculosis, aged twenty-five) and who caused a sensation when her revelatory diary The Journal of Marie Bashkirtseff (1890) was published in an English translation by the poet Mathilde Blind, a few months after 
Levy's death. Reviewing the Cameo edition of A Minor Poet, both Graham R. Tomson and

E. K. Chambers express the opinion that Levy's poems are more self-revelatory than Bashkirtseff's diary; the former claims that 'Marie Bashkirtseff never revealed more - nay, never as much - of her true "inner consciousness" in her much-talked-of diary than has the author of "A Minor Poet"' (667), while the latter considers Levy’s poems 'a human document at least as rich with suggestion as the much discussed diary of Marie Bashkirtseff' (367). The sketches (pictorial and biographical) included in the Pall Mall Gazette therefore whet the reader's appetite for A Minor Poet, which promises to unveil Levy through both the poems and the frontispiece portrait; highly appropriate to a series named 'Cameo'. 7 The volume itself is also subtly feminised in the description as 'delicately clad' (3) reinforcing the promise that the mysterious and tragic Levy might be disrobed through its pages.

\section{'I can see her now': Photographic Reminiscences of Levy}

Following her death, Levy's photograph is invoked in memoirs, reminiscences, and critical reviews written by individuals who she encountered in life, and also by those she never met. An example of the latter is the journalist and art critic Harry Quilter. Opening his 'Amy Levy: A Reminiscence and a Criticism' (1892) Quilter recounts visiting an inn in Cornwall, where he sees Levy's photograph for the first time:

The walls were covered with pictures, $[\ldots]$ The bookcase was literally crammed with books $[\ldots]$ The mantelpiece too was crowded with photographs, and some big white lilies stood in pots in front of the lattice windows. Amongst the photographs on the mantelpiece, one was of a small, dark girl, of unmistakably Jewish type, with eyes that seemed too large for the delicate features, and far too sad for their youthfulness of 
line and contour. In its way I had rarely seen a face which was at once so interesting, so intellectual, so beautiful, and, alas! so unhappy. (136-138)

Quilter's hostess then explains that Levy was a visitor from Bloomsbury who came down to be nursed (138). Hunt Beckman confirms that Levy had indeed travelled to Cornwall in autumn 1885 as a 'therapeutic retreat' for her depression (115). ${ }^{8}$ Lacking direct acquaintance, Quilter uses his encounter with Levy's photograph to fantasise about her character, a physiognomic fabrication founded on the 'lines and contours' of her face. Even before he reaches her portrait, his description of the photograph's setting is suffused with suggestive symbolism - the funereal lilies, the 'lattice windows' (Levy's poems often feature speakers gazing out of windows, for example, Xantippe 'leaning from the lattice', 357), and the positioning of her face among a 'crowd', evoking an over-populated London, and the ‘crammed' literary marketplace in which Levy cuts an unhappy figure.

Quilter categorises Levy as a typical 'Jewish type', diagnosing melancholy and intellectualism in her 'too large' eyes. His allusion to Jewish physiognomy recalls ethnological studies of race published in the latter half of the nineteenth century, such as Robert Knox's The Races of Man (1862) which described 'Jewish features' in antisemitic terms. Later in the century, Joseph Jacobs collaborated with Francis Galton to create composite photographs of 'the Jewish type', published in The Photographic News in 1885. Though Jacobs was himself Jewish, the resulting article plays into the stereotypical notion that: 'Most people can tell a Jew when they see one' (218), emphasising 'Jewish eyes' as particularly characteristic (220). As Sander Gilman has shown, fin-de-siècle race science tended to associate the 'Jewish brain' with both genius and madness, arguing that these degenerative traits could be discerned in the facial features. ${ }^{9}$ For example, in The Man of Genius, Cesare Lombroso (1889) observes: 'It is curious to note that the Jewish elements in 
the population furnish four and even six times as many lunatics as the rest of the population', drawing a 'correlation between genius and insanity' (136). He describes the 'man of genius' as typically exhibiting 'elevation of the forehead' and 'great vivacity of the eyes' (14-15).

Physiognomic evidence was not just reserved for geniuses and the insane. As E. K. Chambers explains in his essay 'Poetry and Pessimism' (1892), the strains of modern life had 'bitten their mark' into the features of the general population:

Flesh is ever but a transparent veil to spirit, and of this suffering we bear the plain sign upon our brows. It needs no wide knowledge of art to realise that the faces which Gainsborough painted differ notably in character and expression from those which fill the walls of a modern picture-gallery. The new type is as beautiful perhaps, more deeply intellectual, but certainly far more sad. It is scarcely fantastic to suggest that Leonardo's ironically named La Gioconda, an alien to our great-grandmothers, is curiously at home among the women of our own generation. By the same spirit our philosophy is coloured. (368)

Chambers clearly saw Levy's face as representative of this 'new type'. Describing her as 'modern to the core' in his essay on A Minor Poet, he examines her face for evidence of her 'secret':

One turns instinctively to the portrait facing the title-page to see what manner of woman she was who could write thus, but the secret is hardly revealed. There is a face of no special beauty, the brow and eyes burdened with a weight of thought, the lips set as if in some reticence of sorrow. Baffled rather than satisfied, one goes back to the poems, anxious if possible to win the mystery from themselves. [...] Brief as these 
records are, it is yet possible to decipher in them some image of the personality by which they were dictated. (369)

Drawing on Pater, Chambers portrays Levy as a Gioconda for the modern age; her ambiguous expression only hints at her 'sorrow': her lips are reticent, but her poems are voluble, offering an 'image' of the 'personality' that her portrait refuses the viewer.

Returning to Quilter's essay, it is little surprise that his description places emphasis on Levy's 'too large' eyes as both 'typically' Jewish, and as symptomatic of her intelligence and her sorrow - an observation that recurs in other reminiscences. Quilter goes on to state that he had previously rejected one of Levy's stories (he does not specify which) for the Universal Review, where he was editor. He explains that, after encountering her photograph, he returned to her work with renewed interest: 'I read Miss Meredith as perhaps a critic should read every book if he would do entire justice to its author - that is to say, with personal sympathy, and a belief that I should find the story extremely interesting' (139). Praising this novel and Reuben Sachs, he still cannot resist expressing his view that there is 'something positively inhuman in such work proceeding from the lips of one who was scarcely more than a girl' (145). Thus, although his estimation of her work is complimentary, Quilter's critical appreciation is founded on a romanticised vision of Levy, inspired by his fantasising around the photograph of this 'young and lovely girl' (148).

Even those that that actually met Levy represent her in similarly romanticised terms. The prolific Irish writer Katharine Tynan later published her reminiscence of encountering Levy at the Literary Ladies dinner in May 1889:

Most of us smoked after dinner. I remember Amy Levy, that tragic personality, who had so short a time to live, sitting opposite to me, her charming little Eastern face 
dreamy in a cloud of tobacco-smoke. [...] She died in the following autumn, by her own hand. [...] But I dare say she was doomed, poor, gifted little soul. (290)

Tynan's emphasis on Levy’s ‘Eastern face' echoes Quilter's 'dark girl, of unmistakably Jewish type', exoticising Levy as a foreign other. As Hunt Beckman notes: 'Levy's contemporaries $[\ldots]$ were unable to see her clearly because her image was obscured by their tendency to see a "Jewess" as mysterious, exotic and foreign' (4). Building on this, I propose that the emphasis on Levy's face - in Tynan's case 'framed' through a cloud of tobaccosmoke - suggests that Tynan and Quilter's impressions are mediated through their posthumous encounters with Levy's photographic portrait, which was presented in a gently blurred oval, after the fact of her suicide was revealed. They then re-read her face through these events, as through a clouded lens.

In keeping with this markedly photographic aesthetic, recollections of Levy often adopt a monochromatic palette, emphasising her dark hair and eyes in contrast to her white gowns and pale skin. This can be seen in Louise Chandler Moulton's recollection of meeting Levy at a party in 1889 :

She invited me to the University Club for a tea [...] I can see her now, as she poured that tea, that July afternoon, at the little round table, in one of the home-like sitting rooms of the University Club. She wore a white gown, as, indeed, she almost always did. Her face, delicate as an Easter lily, matched the cream-white of her dress. It was a face illuminated by great, dark eyes, from which looked the sweetest, saddest soul that ever fell out of love with the world. (385) 
Moulton's reminiscence has the immediacy of a snapshot ('I can see her now'), freezing Levy in a monochromatic tableau. Other accounts also comment on Levy's pale gowns; for example, a 'lady correspondent' in the Pall Mall Gazette (possibly Tynan again) recalls meeting Levy at the Literary Ladies Dinner: 'her delicate dark beauty set off by a dress of cream-coloured satin and coral ornaments. She was rather silent, smoked her cigarettes very thoughtfully, but made a brilliant little speech à propos of literature as a profession' ('Today's Tittle-Tattle' 6). Contemplating Levy's preference for light-coloured gowns in her final year of life, Hunt Beckman speculates that 'Levy might have been trying to create an image - a "look" - that would make her a memorable literary personality' (184). She notes that Levy was inspired by Madame de Staël's Corinne, who dresses in 'a robe of virgin white' (20) when performing her poetry. While this could be the case, it is also worth bearing in mind that the dead conventionally appear clad in white - redolent of both winding sheets and etherealised spirituality - so the prevalence of this colour in posthumous portraits of Levy may be a case of retrospective foreshadowing, rather than founded on actual fact. As already noted, Levy wears a dark-coloured dress in the Montabone photograph, and her letters mention gowns of maize, brown, orange and black (Hunt Beckman 184). It is therefore plausible that in remembering Levy, commentators retroactively drain her of colour, transforming her into a ghostly image more suited to her eventual demise.

In addition to this monochromatic aesthetic, another recurring feature in posthumous descriptions of Levy is their emphasis on her silence. This reticence that was partly due to her hearing loss, which worsened in 1888 (Hunt Beckman 150). Michael Field (Katharine Bradley and Edith Cooper), who never met Levy in life, allude to this element of her character when visiting Dollie and Ernest Radford in 1891: 'The husband and wife knew Amy Levy \& a delightful silent smoking companion she could be. She was deaf and often quiet' (Field 33v). Diminutive (the adjectives 'small', 'little', 'delicate' recur across these 
descriptions), silent and monochromatic, Levy, even in life, sounds uncannily like a photograph. The Montabone portrait becomes the preferred symbol, mediating reminiscences of the living woman, as Levy becomes a conveniently voiceless image onto which various interpretations can be projected.

\section{'A ghost, a phantom, a nullity': Grant Allen's Amy Levy}

Although the reminiscences discussed above are troubling in various ways, the most problematic posthumous representation of Amy Levy comes from Grant Allen. Allen met Levy on a holiday in Dorking in 1889, a few months before her death. Less than a year after her suicide, Allen invoked her in his essay 'The Girl of the Future' (1890), representing Levy as a victim of higher education, which he regarded as endangering women's 'maternal functions': 'A few hundred little pale Amy Levys sacrificed on the way are as nothing before the face of our fashionable Juggernaut. Newnham has slain its thousands and Girton its tens of thousands' $(52,56)$. However, although this statement has been frequently cited by critics, few scholars have paid attention to Allen's more substantial representation of Levy in his 1894 novel Under Sealed Orders. The plot, centred on Russian nihilism, is bursting with adventure, conspiracy, espionage, and international travel, and features three New Woman characters: Sacha Cazalet, Ionê Dracopoli and Hope Braithwaite (nicknamed Blackbird). In one of the novel's many subplots, the trio form a 'miniature phalanstery' (82), doing their own cooking and cleaning - an arrangement loosely based on the radical household of Grace and Clementina Black at Fitzroy Street. ${ }^{10}$ In creating these characters, Allen draws on other real-life 'New Women'; for example, Ionê, who travels alone in Morocco in male costume, is based on the writer Ménie Muriel Dowie, who travelled through the Carpathian Mountains in 1890, culminating in a lecture tour promoting her book A Girl in the Karpathians (1891). ${ }^{11}$ 
Throughout the novel, it is clear that Ionê represents Allen's eugenic ideal; healthy, bold, and yet still 'womanly', she resembles his other 'eugenically-fit' heroines such as Lois Cayley in Miss Cayley's Adventures.

Ionê's irrepressible energy and robust physical health contrasts with the portrayal of Blackbird, a melancholic weakling who is physically and emotionally stunted by her extensive education. This is her first appearance in the novel, from the perspective of the strapping hero Owen:

Owen peered into the long chair whence the voice proceeded, and saw a frail little woman stretched out in it lazily - a frail little woman who ought to have been eighteen, to judge by her development, but who, as Sacha had already informed him, was really twenty-seven. She was tiny, like a doll [...] she looked too fragile for this earth - a mere delicate piece of semi-transparent Dresden china. [...] Such eyes Owen had never seen in his life before. They were black and lustrous, and liquid like a gazelle's; and they turned upon him plaintively and flooded him with sad light every time she spoke to him. [...] A profound pity for her evident feebleness was the first feeling she inspired. 'Poor wee little thing!' one felt inclined to say as one saw her.

Learning that Blackbird has studied 'dead tongues at Oxford' (84) and is proficient in music and chemistry, Owen reacts with alarm: 'You don't mean to say you combine them all in your own sole person?' to which Blackbird responds: 'And not much of a person at that! [...] It's the fault of the system. My raw material all went off in brain and nerves, I'm afraid' (86). ${ }^{12}$ She complains that she has been stuffed with learning like a 'Strasbourg goose' - the same phrase Allen employs in 'The Girl of the Future' (56) - leaving her physically and 
emotionally underdeveloped - as she repeatedly states, she is not a 'real' woman at all, but 'a ghost, a phantom, a nullity' (262). Refusing a proposal of marriage from Henley Stokes later in novel, she explains that she is 'in body a child, no more fit to love or be loved in the way you think than a four-year-old baby' (256). Unable to fulfil her natural function as a woman, Blackbird decides to end her life. As Henley weeps over her body, castigating himself for her death, Allen makes it clear where he believes the blame truly lies: "“And to think I should have killed her!" Sacha bent over the pale corpse with big tears in her eyes. "Not you, not you, dear Henley," she said, gazing at it; "but her parents and teachers"” (262).

As details of age, appearance and education suggest, Blackbird is clearly based on Levy. Moreover, Peter Morton notes that: 'The ditties Allen puts into Blackbird's mouth are derived from Levy's' (120). Allen stops short of direct quotation from Levy's poems, but does cite some of her poetic influences: Swinburne, Tennyson, Andrew Lang, and paraphrases her verse, as Blackbird sings 'a song about how sweet 'twould be these cramping bonds to sever, to lie beneath the soil, free from earth's care and moil, life's round of joyless toil, and sleep one dreamless sleep for ever' (190). Pullen notes that Levy shared the MS for A London Plane-Tree with Allen shortly before her death (177), so it is little surprise that Allen's pastiche resembles poems from that volume, including 'The End of the Day', 'The Promise of Sleep' and 'In the Black Forest'. Levy's work would have been fresh in his mind, since Allen completed Under Sealed Orders in 1891 - much closer to Levy's death than the eventual publication date of 1894 suggests (Morton 120).

The American edition of the novel features illustrations by H. C. Edwards, which further underscore the allusions to Levy. ${ }^{13}$ Two illustrations depict Blackbird; the first, accompanying her first appearance in the novel, emphasises her supine weakness in contrast to the vibrant Ionê and Sacha [Figure 6]. Indeed, she looks dead already, her eyes closed as if in pain. The image closely resembles Levy, with dark eyebrows and hair contrasting against 
pale skin, echoing the monochromatic descriptions discussed earlier. The second illustration [Figure 7] depicts Blackbird's corpse at the scene of her suicide:

Within, very motionless, Blackbird lay across the bed, in a simple black grenadine evening dress, her feet just touching the ground, her head thrown on one side, as if listless, on the pillow. She was sleeping soundly - at rest at last. Her face was very white. Her thin hands were bloodless. [...]

By her side, on a little table, lay a corked bottle. Against it a piece of paper was conspicuously titled:

‘Don’t touch, for Heaven's sake. Prussic acid. Very poisonous. The fumes would kill.' (259)

In envisioning Blackbird's suicide, Allen derives inspiration from Levy's work - specifically the 'phial' containing 'drowsy juices' that appears in 'A Minor Poet' $(370,372)$. As Blackbird's suicide note explains, the prussic acid is created from distilled laurel leaves: 'Do you remember, all last summer, I was always messing about in the laboratory with laurelleaves? Well, laurel-leaves contain amygdalin, and from amygdalin you can distil hydrocyanic acid — that's the chemical name of it. I might have made it from drugs, but this way was prettier' (261). Allen, who specialised in botanicals, is correct; laurel does indeed include amygdalin, which can produce cyanide ('prussic acid') if distilled. But is it going too far to speculate that Allen also includes the word 'amygdalin' because it also plays on Levy's first name? In any case, Levy's death was the result of inhaling charcoal, a different 'concentration of arboreal matter' (Thomas 129), but the real details of Levy's suicide are hinted at in the word 'fumes'. Both Levy and Blackbird die in small, locked rooms, and Blackbird's 'pretty' deathbed scene is staged in a manner that recalls specific details of 
Levy's suicide; she was apparently found in bed surrounded by vases of flowers (Hunt Beckman 209), as well as resembling the postmortem tableau of The Romance of a Shop.

Indeed, this posed mise en scene invokes another subplot of Under Sealed Orders; the photographic studio owned by Mr Hayward, which provides a cover for his Nihilist operations. Though the two plotlines are not explicitly connected in the novel, it is worth noting Blackbird and Hayward both use their workshops as a decoy for murkier activities photographic endeavour cloaks the preparation of a terrorist plot, while the chemical 'experiment' with laurel leaves covers up Blackbird's suicidal intentions. Therefore, while Blackbird's narrative may not appear to have much to do with the central plot focusing on Russian Nihilism, her death-drive has roots in philosophical pessimism, which is also a key strain in the Nihilist movement. This was an area of philosophy in which Levy herself was well-versed, as she read Arthur Schopenhauer and translated the works of Heinrich Heine. In keeping with his Nihilist training, Owen repeatedly expresses his willingness to die if the cause demands it, telling Mr Hayward: 'if it's needful I must die, I die willingly, ungrudgingly' (218). Similarly, Blackbird presents her suicide as a rational acceptance of her fate: 'it was unreasonable for me to do anything else on earth but fall asleep' (260-261). Both characters articulate what Angela Leighton describes as Levy's own ‘cool, philosophic attitude in the face of a morally senseless world', as expressed in her poetry (591). According to Allen's novel, Owen, Blackbird and Levy are all 'under sealed orders', in the sense that all are condemned, unwittingly, by their early training; moulded to fit others' desires and ambitions - with fatal consequences.

\section{Poetic Remains: Amy Levy's Sapphic Legacy}


The representation of Levy's death draws on an array of well-established myths about creative genius. As we saw earlier in the Pall Mall Gazette, Levy was likened to Thomas Chatterton and other 'inheritors of unfulfilled renown' (a phrase from Percy Bysshe Shelley’s 1821 elegy for John Keats, Adonais). ${ }^{14}$ The stereotype of the impoverished, doomed genius haunts Levy's posthumous portrayal, contributing to the fallacy that she died in a garret, for instance, and to the rumours that her suicide was precipitated by receiving critical reviews of Reuben Sachs - recalling speculation that the consumptive Keats was finally killed off by a vicious review. But while Levy's posthumous portrayal draws on myths of misunderstood male genius, it also taps into a distinctive tradition of the doomed Romantic 'poetess'. Blackbird's death in Under Sealed Orders closely resembles that of the Romantic poet L.E.L. (Laetitia Elizabeth Landon) who was found with bottle of prussic acid in her hand (Byron). L.E.L., along with fellow Romantic poet Felicia Hemans, was inspired by de Staël's Corinne, writing poems that express the conviction that love and learning are incompatible. As Claire Brock has suggested, during the Romantic period, fame became increasingly feminised, with writers such as de Staël skilfully forging a celebrity image that took full advantage of increased opportunities for publicity and self-promotion. However, while de Staël's works Corinne and Delphine 'provide effective manifestos for the conduct of the famous female' (152), they also suggest that, for women, death and fame are entangled; while often concluding with 'the suicide of the celebrated heroine and thus apparently suggesting that the only happy ending such a woman was death', fame continues to concern these characters: 'Even in dying, these women were mindful of their reputation' (152). Elsewhere, Samantha Matthews also observes the centrality of death to Romantic representations of women poets and fame. For example, in 'The Grave of a Poetess', Hemans contemplates the premature death of fellow poet Mary Tighe in order to reflect on her own posthumous reputation. For Hemans, de Staël, Landon and their peers, 'the high-profile feminine literary body, [...] is 
also overwhelmingly doomed, dying, or dead' (Matthews 77). As we have seen, Levy's own self-fashioning may have drawn on de Staël's doomed Corinne, forging a link between her poetic persona and that of earlier Romantic women writers.

This vexed relationship between 'Woman and Fame' (the title of one of Hemans' poems) links back to the Ancient Greek poet Sappho, who, according to Ovid's myth, leapt from the Leucadian cliffs due to unrequited love for the fisherman Phaon. As Yopie Prins has shown, the 'last song' of Sappho proved a hugely popular subject for women poets throughout the nineteenth century, inspiring works by Hemans, L. E. L., Elizabeth Barrett Browning, Augusta Webster, Christina Rossetti, and others. Hunt Beckman speculates that towards the end of her life, Levy also played 'with the idea of herself as another Sappho, the protagonist in one last narrative fashioned to give form and meaning to her end' (209). Levy, who studied classical languages at Cambridge, clearly had Sappho in mind at the time of her death, as three poems in A London Plane-Tree appear under the heading 'Songs from THE NEW PHAON'.. ${ }^{15}$ In portraying Levy as Blackbird, Allen also draws on these Sapphic connotations. For example, Sacha's explanation of her nickname: 'she's so tiny and so dark, and she's got so much voice in her for such a wee little bit of a thing' (84) echoes Lucian's description of Sappho as 'very ill-favoured, being small and dark, like a nightingale with illshapen wings enfolding a tiny body' (qtd. Edmonds 161).

The fatal laurel leaves also invoke the classical symbol of poetic genius, associated with Apollo and the muses. Observing them earlier in the novel, Owen speculates that: 'She wanted to extract poetic inspiration from them, perhaps, for her melancholy music' (158). Blackbird's suicide is thus highly symbolic: her poetic aspiration is linked directly to her death. She is effectively killed by her own creative ambition. Allen played on a similar idea in his elegy 'For Amy Levy's Urn' in which he imagines Levy scaling the 'peaks of imagined rhyme' before fainting and falling to her death: 
This bitter age that pits our maids with men

Wore out her woman's heart before its time:

Too wan and pale,

She strove to scale

The icy peaks of unimagined rhyme.

There, worlds broke sunless on her frightened ken;

The mountain air struck chill on her frail breath:

Fainting she fell, all weary with her climb,

And kissed the soft, sweet lips of pitying death. (21)

Comparing Levy's ambition to climbing Mount Helicon (the mountain of the muses, after which Allen's titles his volume), he describes her as suffering from a form of poetic altitude sickness - she has climbed too high for her abilities. But rather than leaping like the heroic Sappho, the eugenically unfit Levy passively drops into the abyss. As Lyssa Randolph notes, Allen reanimates Levy only to kill her again, punishing her ambition towards lasting literary fame, 'attacking Levy in her own form' and violently incorporating her into his own poetics (215). The title of Allen's poem fits with these classical resonances, referring to the Ancient Greek funerary urn; an object which also features in Ernest Radford's elegy for Levy originally published in the Pall Mall Gazette two days before Allen's poem, entitled 'An Inscription on an Urn':

She chose to die.

Grave here beneath our helpless flowers

'She chose to die.' 
Alas! the sun forsook her sky

What while he gladdened other bowers:

She tasted life — a few sad hours;

And chose to die. (2)

Although Radford's epitaph is less vicious and patronising than Allen's, it still manages to downplay Levy's life and achievements as a 'few sad hours', reducing her significance to the fact of her suicide.

The urn was an appropriate motif, as Levy was in fact the first Jewish woman to be cremated in England. Newspaper accounts provide details of her cremation and funeral, tracing the journey of her body from Balls Pond Cemetery to the crematorium in Woking 'under the charge of Mr. I. Lazarus', and providing details of how long it took to burn:

The body was placed in the furnace at noon, and the incineration occupied about two hours and a half. [...] The ashes were subsequently placed in a small oak box, on which was a plate with the words 'the ashes of Amy Levy,' and recording the date of her birth and cremation. The interment of the ashes took place last Sunday at Balls Pond Cemetery, in the presence of a large gathering of sympathising relatives and friends, including many ladies. The bier on which the box was placed was covered with handsome floral wreaths. ('The Late Miss Amy Levy’759)

The account is strikingly blunt and corporeal in comparison to the airy poetic musings of Allen and Radford. No classical urns here, just a 'small oak box'. As Kate Thomas notes, the media portrayal of Levy's funeral 'resonates with the way that Levy herself repeatedly and impassively stared at death's materiality' (127). Her poems often portray death in a matter-of- 
fact manner, as in the opening lines of 'Epitaph (On a Commonplace Person Who Died in Bed)':

This is the end of him, here he lies:

The dust in his throat, the worm in his eyes,

The mould in his mouth, the turf on his breast;

This is the end of him, this is best. (384)

In her subsequent analysis of Levy's ‘To Death' (translated from Nikolaus Lenau), Thomas argues that Levy anticipates her own cremation, expressing her wish that rather than holding onto the 'ash of feelings dead' those left behind let 'thy singer soar away' (381; Thomas 128). Levy's poem, along with several others in A Minor Poet and A London Plane Tree, contemplates the posthumous representation of the dead - particularly the dead woman - as inherently liminal, poised somewhere between tangibility and ethereality. Consider, for example, 'In the Mile End Road' in which the ghostly beloved passes by the bewildered speaker with 'airy tread' (393), or 'Borderland' in which the speaker is visited by a feminised apparition that 'sheds perfume, / As sweet as love, as soft as death' (391). The dead woman is intangible yet somehow lingeringly present; seductive yet elusive, she seems to be constantly moving into focus, yet somehow always eluding the gaze.

In a similar manner, Levy herself slips past her various commentators, frustrating their attempts to 'capture' her image. As we have seen, her portrait is invoked again and again in biographies, reviews and reminiscences, as commentators insisted on posthumously re-embodying her, in order to reframe her image to meet their own ends. Levy is curiously disembodied in accounts that describe her while alive, portrayed as a 'phantom, a nullity' and as a frozen, monochromatic photograph. Once safely dead, she becomes a face that can be 
read, interpreted, and diagnosed, as if it will eventually yield up its secrets if over-exposed to curious eyes. But as the sheer variety of accounts I have analysed above imply, Levy's image ultimately frustrates any attempt to fix it in one frame or another. As each observer strives to parse the lines of her face, they are haunted by the sense that the 'truth' of Levy evades them all the while.

\section{Conclusion: Our Amy Levys}

The posthumous representation of Amy Levy taps into several problematic legacies around gender, genius, 'madness' and suicide. As we have seen, Levy's portrait is repackaged and marketed as tragic, beautiful, symptomatic of her depression, a signifier of her Jewish identity, in order to sell copies of her books and to promote the parasitic literary productions of others that feed on the tragic mythos surrounding her death. This treatment of Levy's posthumous image resonates in later representations of women poets who committed suicide, such as Charlotte Mew, Sara Teasdale, Sylvia Plath and Anne Sexton. These women's deaths have not only dominated and distorted interpretations of their work, their deaths themselves have also frequently been glamourised - if not necessarily at the time of their demise, as with Levy's, then certainly in later representations. In fact, our own cultural moment seems to be particularly drawn to romanticising and commercialising the 'doomed' women writer. Consider, for example, the 2013 photoshoot in VICE magazine entitled 'Last Words' which depicted models dressed up as famous women writers at the moment of their suicide, including Virginia Woolf standing in a river, Plath kneeling before an oven, and Charlotte Perkins Gilman with chloroform pressed against her face. If VICE had known about Levy, I feel certain they would have included her in the fashion shoot . To do so would have been in keeping with the late-Victorian responses to her death discussed in this essay. 
To conclude, I have shown how Levy's image becomes a posthumous palimpsest, reframed to fit various ideas about female education, poetic identity, genius, and Jewishness, among other issues. I want to close by contemplating Gail Cunningham's words of warning to modern critics and biographers: 'We should be cautious [...] about constructing a figure like Grant Allen's "pallid little Amy Levy"” (86-87). This quotation came back to haunt me in lockdown, as I embarked on a light-hearted project to craft my favourite poets out of discarded toilet rolls [Figure 8]. Glancing at the 'little Amy Levy' sitting on my bookshelf, I realised I was guilty as charged. I had constructed my own Levy - and perhaps my impulse to do so was not dissimilar from that which spawned the 'poetryreincarnation' video, or Grant Allen's when he reanimated Levy as Blackbird. But these are just two of the several 'Amy Levys' out there, and not all of them were as exploitative and manipulative as the examples discussed here. For example, Dollie Radford defended Levy against Allen's attack in her novel One Way of Love (1898), a rewriting of the phalanstery plotline of Under Sealed Orders. Meanwhile, Israel Zangwill fictionalised Levy as Esther Ansell in Children of the Ghetto (1892), in part to atone for his earlier criticism of her work. More recently, Elaine Feinstein eulogised Levy in a 1997 poem, imagining her 'walking by the willows behind the Wren, / and singing to me of Cambridge and unhappiness' (1). As these examples show, in order to keep a celebrity alive in cultural memory, it is necessary that we continue to reconstruct them. But in doing so, in discovering our Amy Levy, we need to be aware of the potentially limiting, damaging mythologies we may be tempted to perpetuate, as well as the legacy we are sustaining, bearing in mind that, when we contemplate Levy's portrait, her image is as much a mirror as it is a photograph.

\footnotetext{
${ }^{1}$ The video can be found here: https://www.youtube.com/watch? $\mathrm{v}=$ wh0iR4MGZwo

${ }^{2}$ All Levy poems are cited from New's edition, unless otherwise stated.

${ }^{3}$ See Vadillo 44-54 for an account of this area in the late nineteenth century.
} 


\footnotetext{
${ }^{4}$ For example, Levy writes in a letter 'Maggie gave me a gorgeous photograph to-day. I am going out now to see about getting a frame for it' (November 10, 1881, qtd. Hunt Beckman 233).

${ }^{5}$ Identity of 'E. Cross' unknown. Hunt Beckman speculates could be Eleanor Cross or Edythe Cross, sisters of John Cross, George Eliot's widow (242). Intriguingly, a report in the 1890 Glasgow Herald mentions that 'A portrait of the late Miss. Amy Levy by a young Jewish artist will probably be seen at the Grosvenor' but I have not discovered a reference to this portrait anywhere else ('Our London Correspondence', 7).

${ }^{6}$ Reproduced in Linda K. Hughes, 'Phantoms of Delight' 168.

${ }^{7}$ Although the 'Cameo' series tends to include an illustrated frontispiece, this is not usually a portrait of the author. For example, A. Mary F. Robinson's Lyrics contains a detail from Botticelli’s Spring.

${ }^{8}$ Levy published a travel account, 'Out of the World' (January 1886) inspired by this visit.

${ }^{9}$ In her own writings, Levy occasionally appeals to these theories of racial hereditary, writing, for example, in 'Jewish Children' (1886) that 'mental precocity' is 'nearly always' the 'sign of a highly developed nervous organisation $[\ldots]$ the Jewish child, descendant of many city-bred ancestors, as he is, is apt to be a very complicated little bundle of nerves indeed' (530).

${ }^{10}$ For a discussion of their living arrangements, see Vadillo 52.

${ }^{11}$ In particular, the scene in which Ionê is photographed in her travelling costume for The Graphic draws on Dowie's own trouser-clad image which appeared on the cover of her book and was reprinted in The Illustrated London News.

${ }^{12}$ Through this scientific aspect, Allen may also have had in mind another recent death: that of the poet, philosopher and scientist Constance Naden, who died on 23 December 1889, aged thirty-one, after operation to remove ovarian cysts. Like Levy, Naden's death was also blamed on female education; in a letter of condolence, Herbert Spencer praises Naden's intelligence but expresses his belief that 'in her case, as in other cases, the mental powers so highly developed in a woman are in some measure abnormal, and involve a physiological cost which the feminine organization will not bear without injury more or less profound' ('Letter from Herbert Spencer' 89; 90). Although he did not comment publicly on Naden's death, Allen, an ardent follower of Spencer, would likely have agreed. In Under Sealed Orders, Blackbird appears to combine some of Naden's qualities with Levy's; she is a 'poet and botanist' like the polymathic Naden (while Levy, as far as I know, had no interest in science or botany).

${ }^{13}$ Likely Harry C. Edwards, a painter and illustrator who contributed work to The Saturday Evening Post.

${ }^{14}$ In a piece entitled 'Science and Women' in the Women's Penny Paper, the anonymous author refutes Allen's 'The Girl of the Future' by drawing comparison to underappreciated male poets who also died young: 'The ghost of poor Amy Levy is invoked with great effect till one recalls such names as Keats or "poor Chatterton," for neither of whom Girton can be held responsible' (530).

${ }^{15}$ As Hunt Beckman notes, it is unusual that Levy appears to align the speaker's voice with Phaon rather than Sappho, positioning herself as the object rather than the subject of Sappho's unrequited desires.
}

\section{$\underline{\text { Works Cited }}$}

Allen, Grant. 'For Amy Levy's Urn'. The Lower Slopes. London: Elkin Mathews and John Lane, 1894. 21.

---. 'The Girl of the Future'. Universal Review 7 (May 1890): 49-64.

---. Under Sealed Orders [1894]. London: Chatto \& Windus, 1914.

---. Under Sealed Orders: A Novel of Love and Adventure, illustrated by H.C. Edwards. New York; Grosset \& Dunlap, 1896. https://catalog.hathitrust.org/Record/100262355

'The Late Miss Amy Levy', Women's Gazette \& Weekly News (September 28, 1889): 759.

Black, Clementina. 'Literary Gossip'. Athenaeum 3232 (October 5, 1889): 457.

Brock, Claire. The Feminization of Fame, 1750-1830. Basingstoke: Palgrave Macmillan, 2006.

Busby, Brian. 'Amy Levy: Blackbird Dying in the Dead of Night' (01 January 2015). The Dusty Bookcase: A Journey Through Canada's Forgotten, Neglected and Supressed Writing. <http://brianbusby.blogspot.co.uk/2015/01/amy-levy-blackbirddying-in-dead-of.html> Accessed 24 July 2016.

Byron, G. 'Landon [married name Maclean], Letitia Elizabeth [pseud. L. E. L.]' (September 
22, 2011). Oxford Dictionary of National Biography.

https://www.oxforddnb.com/view/10.1093/ref:odnb/9780198614128.001.0001/odnb9780198614128-e-15978. Accessed 11 May 2021.

Chambers, E. K. 'Poetry and Pessimism'. The Westminster Review 138 (1892): 366-76. de Staël [Anne Louise Germaine] Madame. Corinne, or Italy [1807]. Trans. Isobel Hill. London: Richard Bentley, 1833.

Edmonds, J. M. [ed. and trans.] Lyra Graeca; being the remains of all the Greek lyrik poets from Eumelus to Timotheus excepting Pindar, Volume I. London: William Heineman, 1922).

Field, Michael [Katharine Bradley's hand]. Works and Days. BL MS Add 46779 (April 14, 1891), fol. 33v.

Feinstein, Elaine. 'Amy Levy' [1997]. 'Introduction'. Amy Levy: Critical Essays. Eds. Naomi Hetherington and Nadia Valman. Athens, Ohio: Ohio University Press, 2010. $1-24$.

Gilman, Sander. The Jew's Body. New York: Routledge, 1991.

Hughes, Linda K. 'Phantoms of Delight: Amy Levy and Romantic Men', Decadent Romanticism 1780-1914. Eds. Kostas Boyiopoulos and Mark Sandy. Surrey: Ashgate, 2015. 161-176.

Hunt Beckman, Linda. Amy Levy: Her Life and Letters. Ohio: Ohio University Press, 2000.

Jacobs, Joseph. 'The Jewish Type, and Galton's Composite Photographs', The Photographic News (24 April 1885) [Appendix D] Amy Levy. Reuben Sachs: A Sketch. Ed. Susan David Bernstein. Plymouth: Broadview, 2006. 218-223.

Knox, Robert. 'From "Of the Coptic, Jewish, and Phoenician Races", The Races of Men' [Appendix D] Amy Levy. Reuben Sachs: A Sketch. Ed. Susan David Bernstein. Plymouth: Broadview, 2006. 215-218.

Leighton, Angela. 'Amy Levy'. Victorian Women Poets: An Anthology. Eds. Angela Leighton and Margaret Reynolds. Oxford: Blackwell, 1995. 589-610.

'Letter from Herbert Spencer to Dr. Lewins, June 10, 1890'. Constance Naden: A Memoir. Ed. William R. Hughes (London: Bickers \& Son; Birmingham: Cornish Brothers, 1890): 89-91.

Levy, Amy. A Minor Poet and Other Verse (Second Edition). London: T. Fisher Unwin, 1891.

---. The Complete Novels and Selected Writings of Amy Levy. Ed. Melvyn New. Florida: University Press of Florida, 1993.

---. 'Jewish Children' [1886]. The Complete Novels and Selected Writings of Amy Levy. Ed. Melvyn New. Florida: University Press of Florida, 1993. 528-531.

---. The Romance of a Shop [1888]. The Complete Novels and Selected Writings of Amy Levy. Ed. Melvyn New. Florida: University Press of Florida, 1993. 59-196.

---. 'Jewish Children' [1886]. The Complete Novels and Selected Writings of Amy Levy. Ed. Melvyn New. Florida: University Press of Florida, 1993. 528-531.

Lombroso, Cesare. The Man of Genius [1889]. London: W. Scott, 1891.

Matthews, Samantha. Poetical Remains: Poets' Graves, Bodies, and Books in the Nineteenth Century. Oxford: Oxford University Press, 2004.

Morton, Peter. The Busiest Man in England: Grant Allen and the Writing Trade, 1875-1900. New York: Palgrave Macmillan, 2005.

Moulton, Louise Chandler. 'Two London Clubs'. The Arena 6 (June-Nov 1892): 384-385. 'Our London Correspondence, 65 Fleet Street', Glasgow Herald (January 15, 1890): 7. 'poetryreincarnations'. 'The Return "Ezra Pound" Sinister Poem virtualy [sic] read by Amy 
Levy Poem animation' [April 11, 2012].

https://www.youtube.com/watch?v=wh0iR4MGZwo. Accessed 11 May 2021.

Price, Warwick James. 'Three Forgotten Poetesses'. The Forum 47 (March 1912): 361-376. Prins, Yopie. Victorian Sappho. Princeton, New Jersey: Princeton University Press, 1999.

Pullen, Christine. The Woman Who Dared: A Biography of Amy Levy. Kingston upon Thames, Kingston University Press, 2010.

Quilter, Harry. 'Amy Levy: A Reminiscence and a Criticism'. Preferences in Art, Life, and Literature. London: Swan Sonnenschein and Co, 1892. 135-149.

Radford, Ernest. 'An Inscription for an Urn', Pall Mall Gazette (September 24, 1889): 2.

Randolph, Lyssa. 'Verse or Vitality? Biological Economies and the New Woman Poet'. Amy Levy: Critical Essays. Eds. Naomi Hetherington and Nadia Valman. Athens, Ohio:

Ohio University Press, 2010. 198-220.

'Today's Tittle-Tattle'. Pall Mall Gazette (September 16, 1889): 6.

Thomas, Kate. 'Lesbian Postmortem at the Fin de Siècle'. The Cambridge Companion to Lesbian Literature, ed. Jodie Medd (New York: Cambridge University Press, 2015). 122-135.

Tomson, Graham R. 'A Minor Poet'. The Illustrated London News (November 21, 1891): 667.

'The Tragedy of Amy Levy'. Pall Mall Gazette 8273 (September 25, 1891): 3.

Tynan, Katharine. Twenty-Five Years: Reminiscences. London: Smith, Elder and Co., 1913.

Vadillo, Ana Parejo. Women Poets and Urban Aestheticism: Passengers of Modernity. London: Palgrave, 2005.

Wilde, Oscar. 'Amy Levy'. Woman's World 3 (1890): 51-52.

'Science and Women'. Women's Penny Paper 2.97 (August 30, 1890), 530.

\section{List of Captions}

Figure 1: Screenshot from 'poetryreincarnations', 'The Return "Ezra Pound" Sinister Poem virtualy [sic] read by Amy Levy Poem animation' [April 11, 2012].

https://www.youtube.com/watch?v=wh0iR4MGZwo. Accessed 11 May 2021.

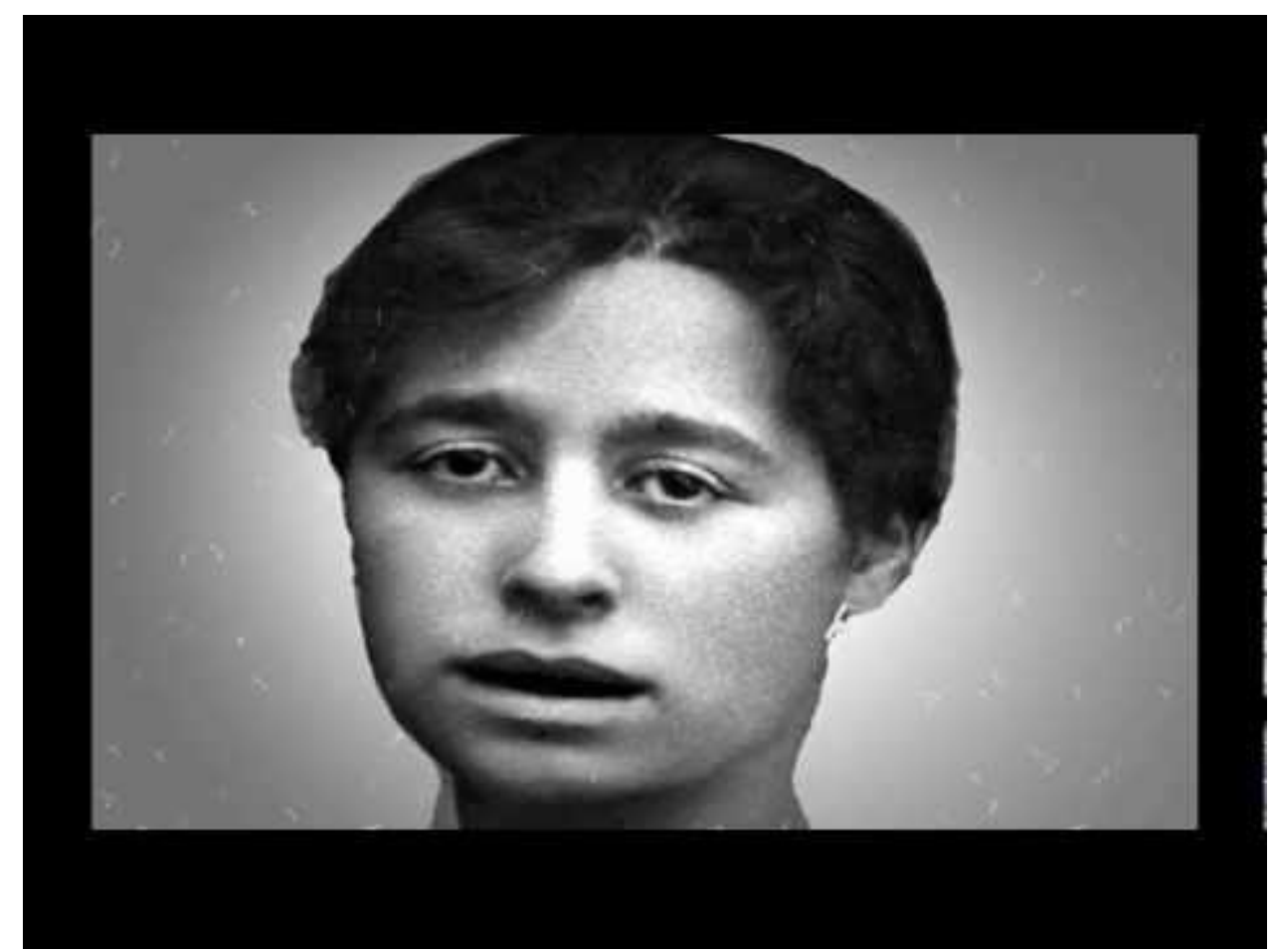


Figure 2: Photograph of Amy Levy, Montabone Studies, Florence, January 1889.

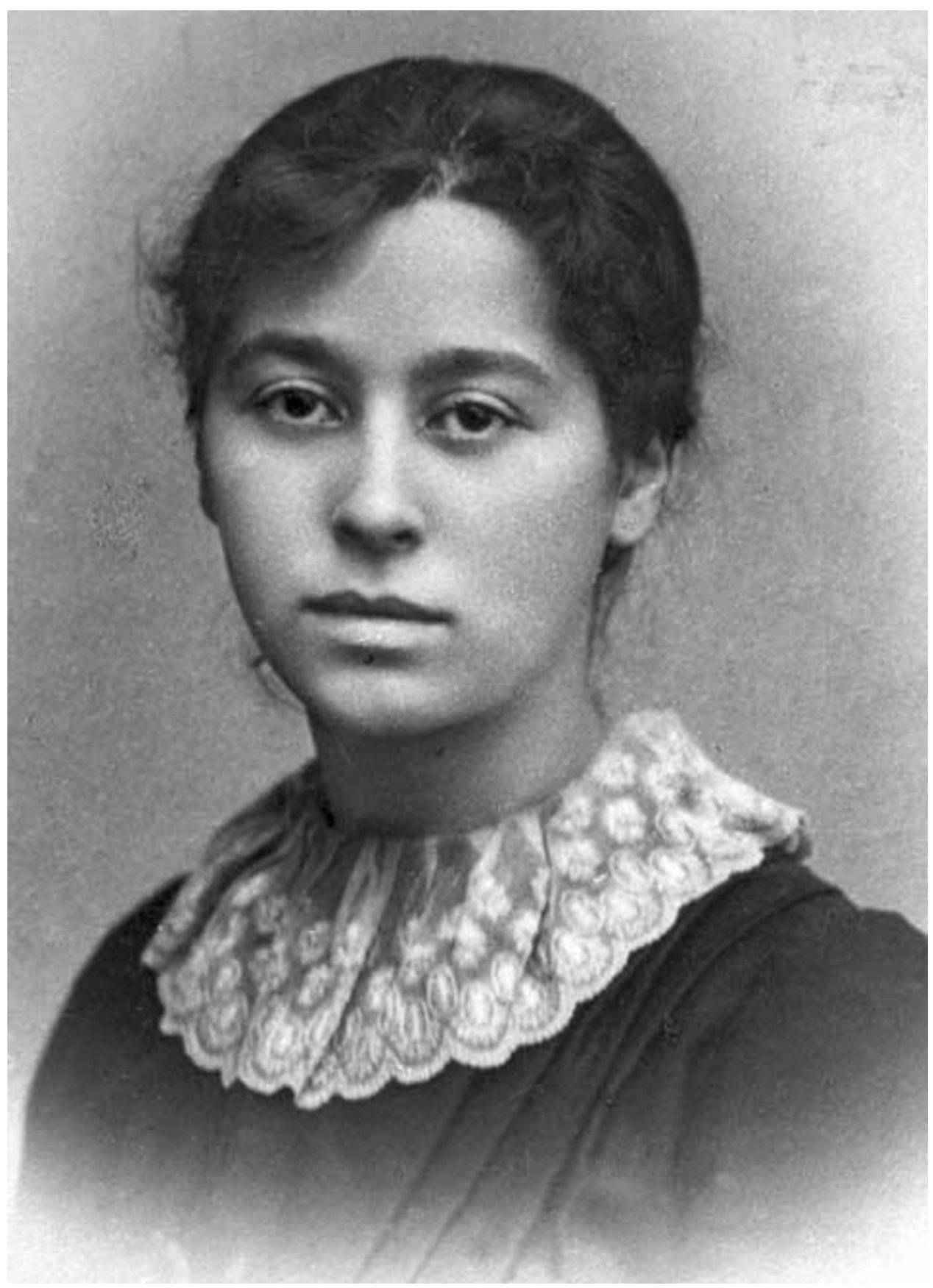

Figure 3: Montabone photograph reprinted in Oscar Wilde, 'Amy Levy', Woman's World 3 (1890): 51. 


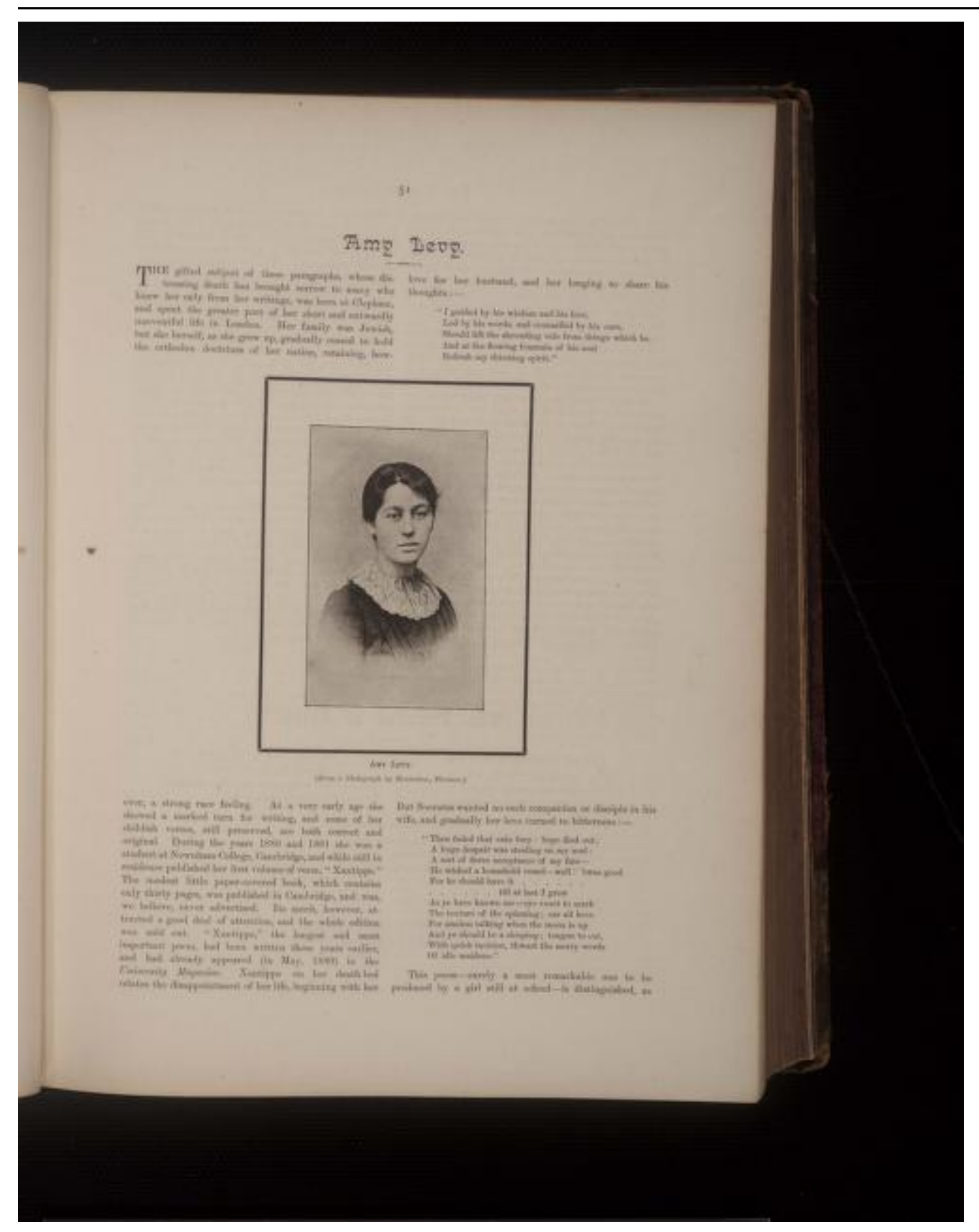

Figure 4: Montabone photograph reprinted as frontispiece to Amy Levy, A Minor Poet and Other Verse (Second Edition). London: T. Fisher Unwin [Cameo Series], 1891. 


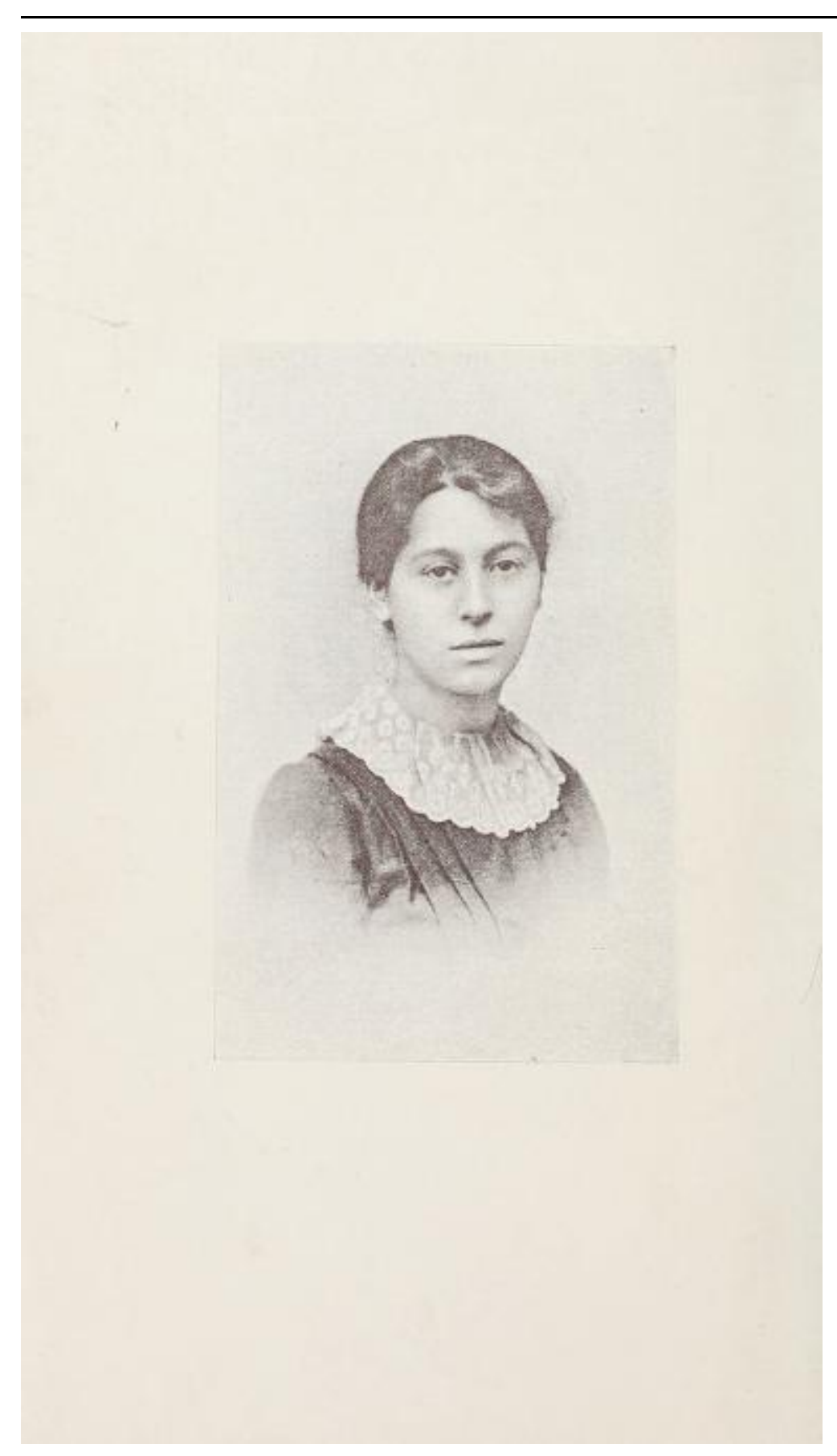

Figure 5: Sketch of Amy Levy by an unknown artist, based on Montabone portrait; detail from 'The Tragedy of Amy Levy', Pall Mall Gazette 8273 (September 25, 1891): 3. 


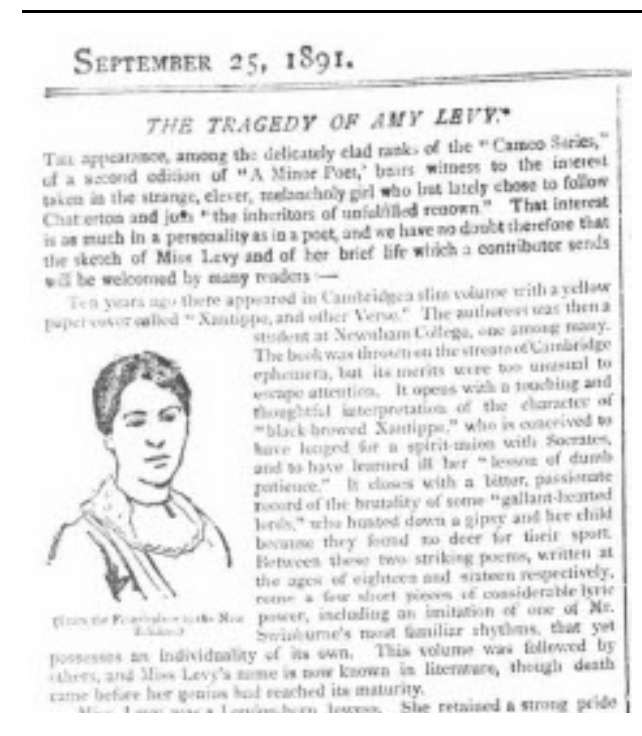

Figure 6: H.C. Edwards' illustration, Grant Allen, Under Sealed Orders: A Novel of Love and Adventure. New York; Grosset \& Dunlap, 1896. Opposite page 88. 


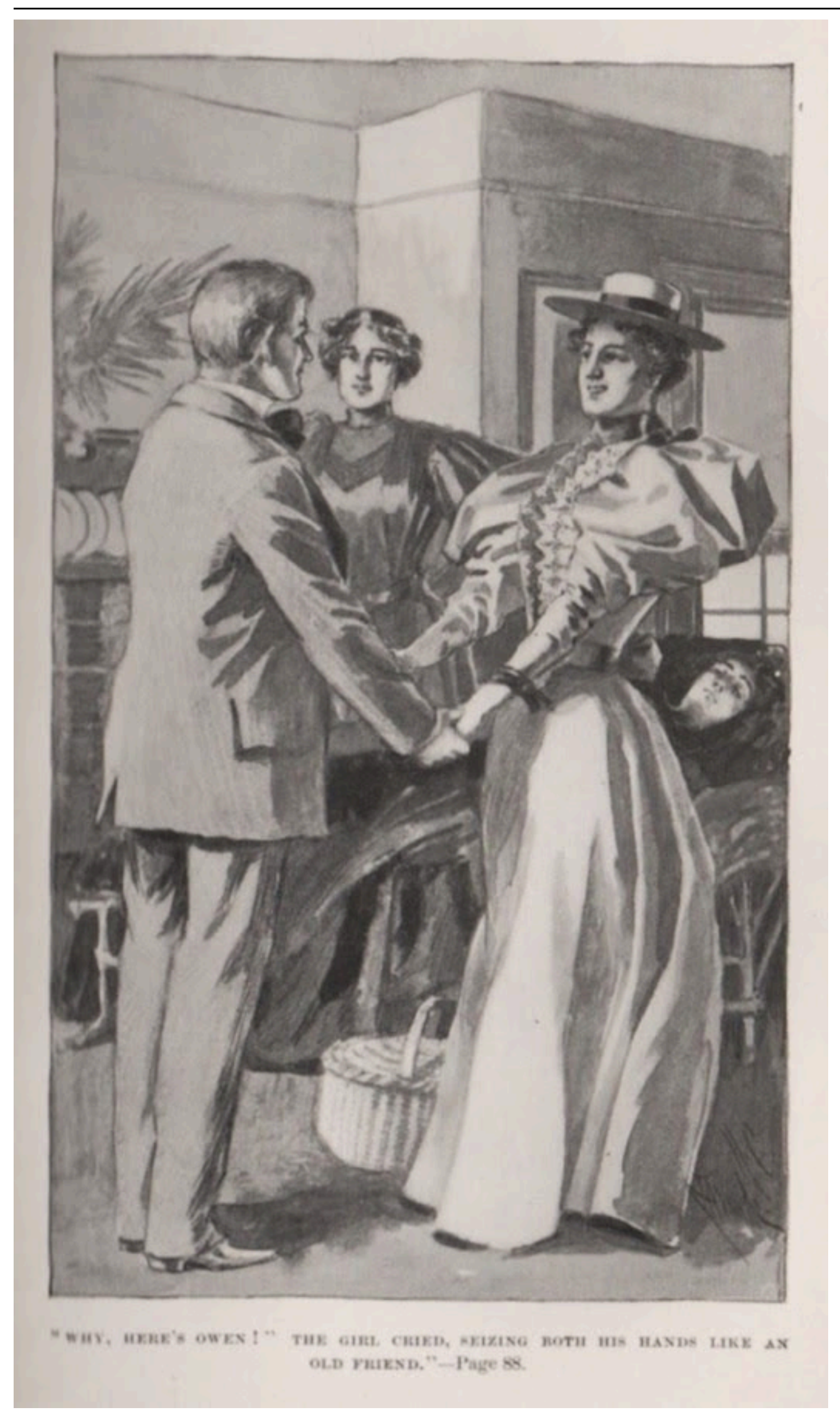


Figure 7: H.C. Edwards' illustration, Grant Allen, Under Sealed Orders: A Novel of Love and Adventure. New York; Grosset \& Dunlap, 1896. Opposite page 258. 


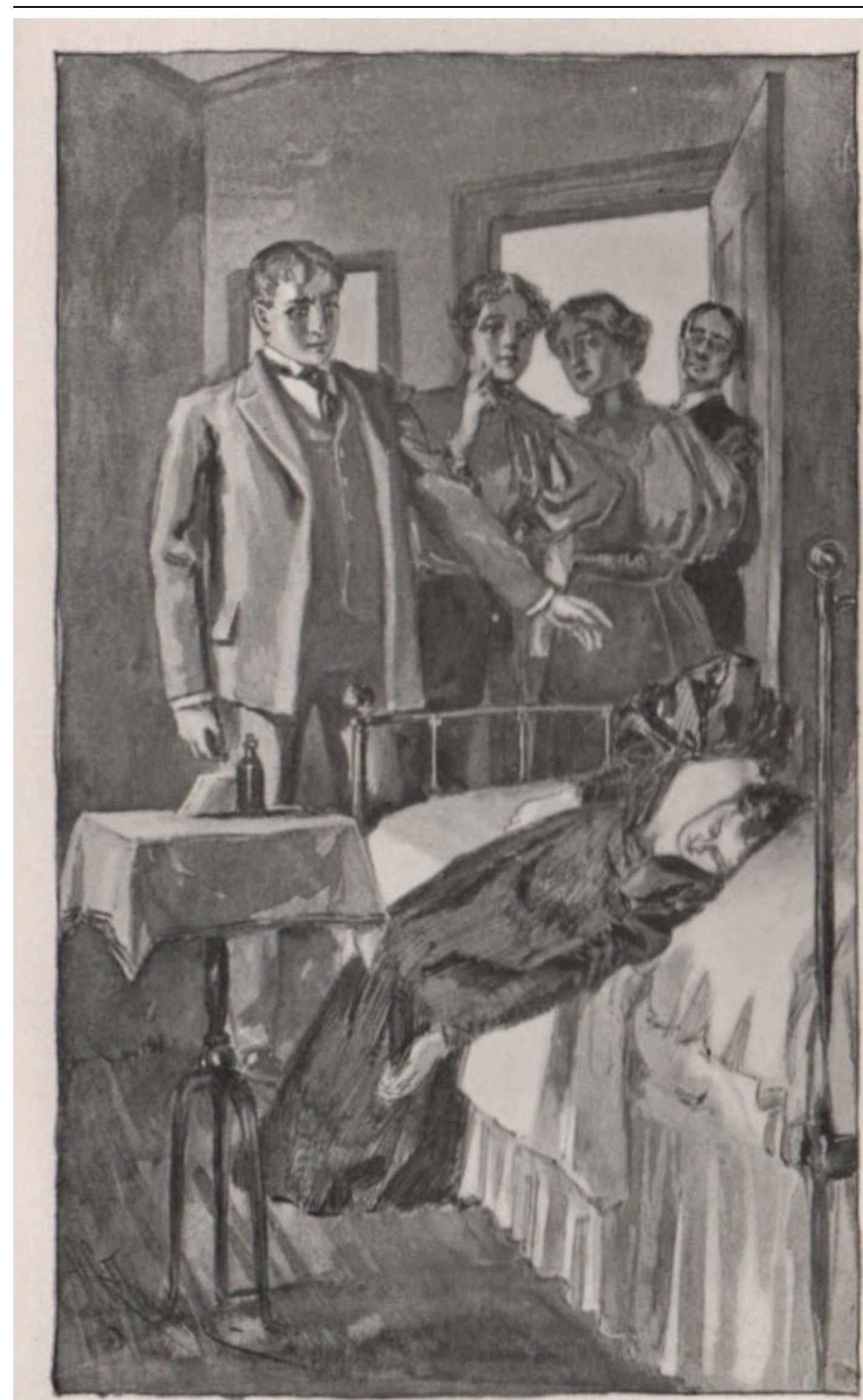

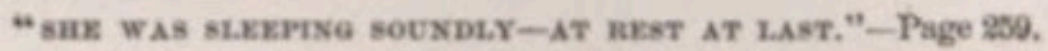


Figure 8: Amy Levy toilet roll 'portrait.' Photograph by author, February 2021.

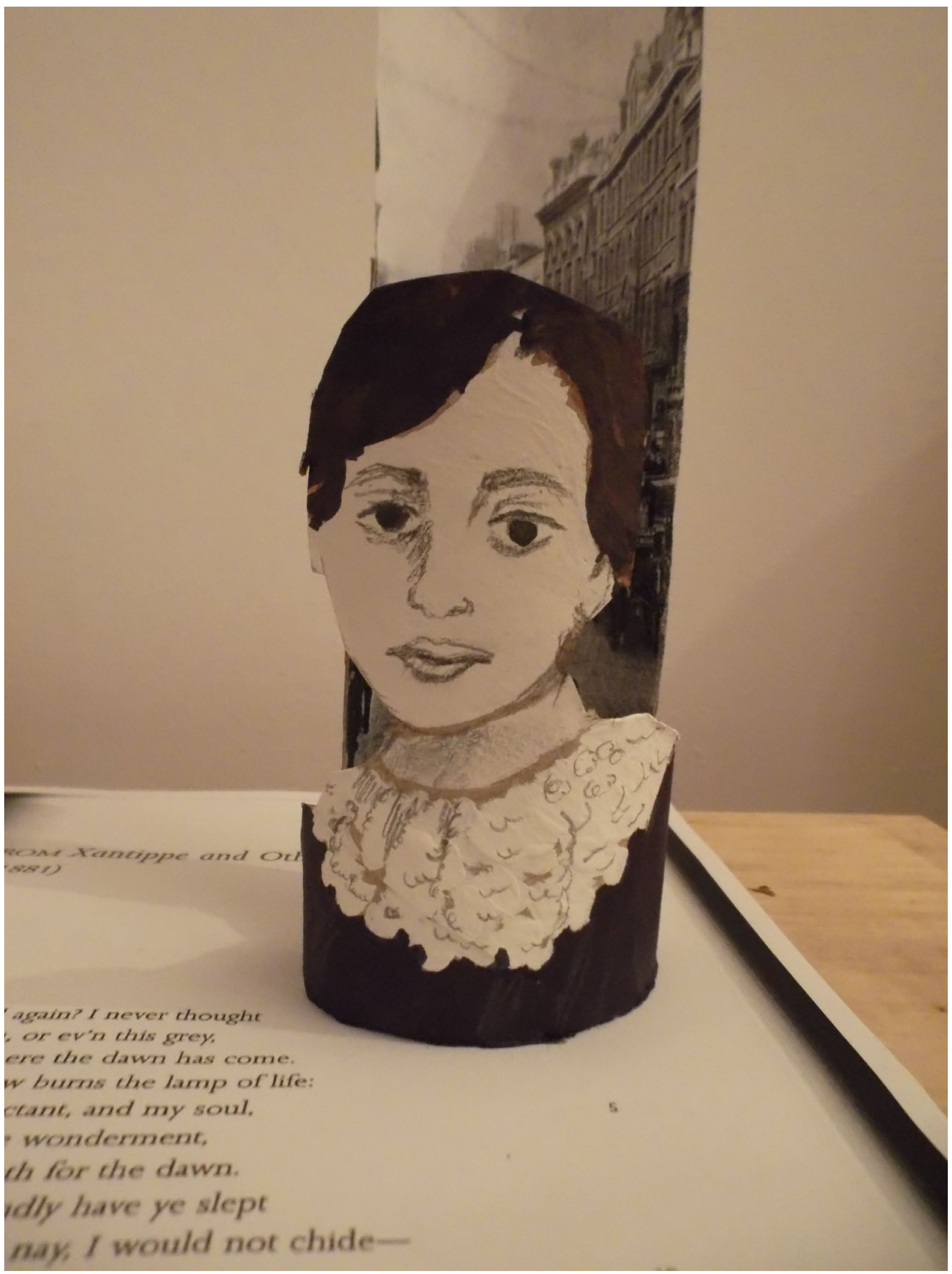

